УДК 340.12

\title{
HUMAN LEGAL NEEDS: CONCEPT, BASIC CLASSIFICATIONS, LEGAL MECHANISM OF SATISFACTION
}

\author{
A. Nakonechna \\ Ivan Franko National University of Lviv, \\ 1, Universytetska Str., Lviv, 79000, Ukraine, \\ e-mail:anna.nakonechna@gmail.com
}

There have been analyzed the concept and legal mechanism of satisfaction of legal needs, and also demonstrated their main classifications.

Such needs have been defined as the needs of people in high-quality legal regulation, as well as in legal assistance.

It has been highlighted the role (possibilities) of each of the main elements (means) of the mechanism of legal regulation in satisfaction of legal human needs, namely: legal personality (legal competence and dispositive legal capacity); legal norm (placed either in normative legal acts, or in contracts, or in case-law cases, etc.); legal relationships; subjective legal rights; legal responsibilities; legal facts as grounds for the emergence, change or termination of such rights); law and order; legalism.

Quality as a characteristic of legal regulation is reflected by the following indicators: 1) the value; 2) economy; 3) effectiveness.

In addition, it has been determined that the need for legal assistance is conditioned by the need to ensure lawful, competent implementation of human rights and freedoms, their protection and restoration in case of violation.

Keywords: human need, need for legal personality, the need for subjective legal rights, the need for legal sources of law and legal facts, the need for law enforcement and interpretative acts

The relevance of the topic is due to the fact that the legal needs accompany each person throughout the life, but almost none of the scholars did not conduct a thorough analysis of their essence and the mechanism of satisfaction.

Comparable to other needs, legal needs are historical entities, and some of them were allocated even by Hegel in his classification of needs. He called them the needs of law and statute [1, p. 114-116]. The organization of legal life in many respects depends on them, and they, in turn, are largely conditioned by previous and current legal development.

So, what social phenomena do belong to the legal ones? The answer to such a question, as P. M. Rabinovych notes, will be conditioned by the general understanding of the term «right». However, this term, as the author emphasizes, has never been, and now is not, and it seems that in the future it will not be meaningfully unified, one-semantic, non-pluralistic [2, p. 18].

Therefore, he tried to interpret the phenomenon of legal needs, in relation to each of the two most common types of positivist legal thinking: sociological and legist.

Thus, according to the standpoint of sociological-positivist legal thinking (in particular, so-called social-natural), the legal need has been defined as the necessity of a person (or a group of people) in the presence and use of certain social conditions, opportunities and means to ensure the exercise of the person's rights and freedoms. The satisfaction of such legal needs, in the opinion of the author, serves as a prerequisite for the realization of the corresponding basic needs of their carrier (of material, social, spiritual needs, etc.), since without realizing such a legal need, the corresponding

(C) Nakonechna A., 2018 
«natural» human rights cannot be realized. Therefore, in light of this, he notes that the legal need in question is instrumental, so to speak, as a «medium» purpose.

The researcher emphasizes that among the identified social opportunities and means, a special role is played by the state-legal phenomena. Therefore, from the standpoint of legist-positivist legal thinking the legal need of a person (or group of people) will consider the need for the availability and use of certain state-legal means to ensure the exercise of its rights and freedoms. First of all, it is about the need to recognize the legal personality of their carrier (including its legal capacity and capacity); in legal norms (contained either in normative legal acts, whether in contracts, or in case-law cases, etc.); in subjective legal rights; in certain legal facts (as the basis for the emergence or change of such rights), in particular, such legal facts as the adoption of law-abiding or legal texts or law enforcement acts.

The satisfaction of such legist-positivist human needs, as the scientist stresses, also serves as one of the prerequisites for the next satisfaction of basic, non-legal content, the needs of their carriers. Therefore, in this sense, legal needs are, in other words, the need for state-legal guarantees (means, levers, «tools») for the implementation of the rights and freedoms of individuals or their groups. And besides, P. M. Rabinovych emphasizes the effective guarantees referred to in the Convention for the Protection of Human Rights and Fundamental Freedoms (Article 13) [2, p. 18-19].

Proceeding from all the foregoing and based on legist-positivist legal thinking, we can propose the following definition of the analyzed concept: legal needs are the needs of people in qualitative and effective legal regulation, as well as in legal assistance.

Legal regulation can be defined as the activity of competent entities, which is carried out with the help of certain legal means. Their set is a mechanism that includes: legal personality (legal ability and capacity); legal norms (contained either in normative legal acts, whether in contracts, or in case-law acts, etc.); legal relationship; subjective legal rights; legal obligations; legal facts as the basis for the emergence, change or termination of such rights), in particular, such legal facts as the adoption of acts of official legal interpretation of lawmakers, or law-restorative, or law-abiding or law-abiding individual legal acts; law and order, legality. So, we briefly characterize the role (possibilities) of each of the main elements (means) of the legal regulation mechanism in meeting the legal needs of a person.

The need for legal personality is due to the fact that neither an individual nor a legal entity can exist and act as a recognition of this property of the latter. It alone makes it possible to do certain actions.

The need for subjective legal rights is due to the fact that every person needs legal certainty of his actions, because it ensures their legitimacy and morality. They serve as a kind of «key» provided by the state for the purpose of carrying out activity on acquisition and consumption, use of certain vital goods: objects of legal relations.

The need for legal norms and legal acts arises from the fact that they legally establish the subjective rights and guarantee their implementation.

The need for legal facts is explained by the fact that they are the basis for the emergence, change or termination of legal relations, for the emergence of subjective rights of citizens in specific legal relationships. In addition, they are a unique means of transferring the person's legal personality into its subjective right, and also constitute the necessary link in the transition from the state normative regulation of social relations to individual legal regulation.

The need for legality is due to the fact that it is a condition for the emergence and functioning of law and order, which is necessary for the ordering of social relations, and thus the prevention of chaos and arbitrariness. 
Regarding to such a characteristic of legal regulation as its quality, it is reflected primarily by the following indicators:

- the value of legal regulation. It is characterized by its positive significance to meet the needs of human existence and development, social communities, associations, and society as a whole;

- economy of legal regulation. It is characterized by the amount of social expenditures needed to achieve its goal;

- the effectiveness of legal regulation. It is characterized by the ratio of real results of this regulation to its goal [3, p. 202].

The need for legal assistance is conditioned by the need to ensure lawful, competent, genuine implementation of human rights and freedoms, their protection and restoration in case of violation.

There are allocated the following types of legal needs:

- according to the spheres of human life:

1) essential (for example, the need for security (security need), etc.);

2) personal (needs for state registration of surname, name and patronymic, state guarantees of religious freedom, etc.);

3) economical (for example, the need for state guarantees of the protection of ownership rights, entrepreneurial activity, employment);

4) political (the need for obtaining citizenship and guaranteeing the state the impossibility of expulsion beyond its borders, the creation of effective mechanisms for the implementation of rights and freedoms by the state, etc.);

5 ) in the field of social protection (the need for more precise provisions on the right to protection of motherhood and childhood; the need to expand the social security system);

6) cultural and spiritual (for example, the need for state guarantees of freedom of literary, artistic, scientific and technical creativity, the preservation of historical monuments and other objects of cultural value, the use of state measures for the return of cultural property that are located abroad, in organizing the state of the museum fund and in providing access to acquaintance with its assets);

- according to the legal-branch basis:

1) constitutional (for example, the need to take part in the management of state affairs, to be elected to the authorities, in recognition of certain acts that do not conform to the constitution of the state);

2) civil (the need to enter into contractual relations of a certain type, in obtaining compensation for moral damage, etc.);

3) family (for example, the need for adoption of children in obtaining child support for maintenance of children or parents);

4) administrative (requirements for obtaining registration, reference and other administrative services, etc.);

5) criminal (for example, the need for prosecution and the imposition of punishment for the committed crimes);

6) financial (need to pay taxes, in particular for the maintenance of public authorities, providing public order and security, etc.);

7) criminal procedural (for example, the need for pre-trial investigation on each fact of revealing signs of a crime, in a fair trial of criminal cases);

8) civil procedural (the need for a court to declare a person incapacitated or limited, in establishing facts of legal significance, in a fair trial of civil cases, etc.);

9) others:

- according to the period of existence: 
1) constant (such are, in particular, the need for normative legal regulation of public relations through the state);

2) temporary (for example, the need for different types of legal aid);

- on the quantitative composition of the carriers:

1) individual (for example, the need of a person to apply to a court for compensation for damage caused by the destruction of his property);

2) collective (the needs of a group of people in the creation of a public association, in the conduct of a peaceful assembly, etc.);

3) «mixed» (for example, the need for referral to a public authority or local government can be either individual or collective);

- according to the legal status of the individual carrier:

a) the legal needs of citizens (the need to elect representatives to state agencies (the head of state, members of parliament), the resolution of issues of national importance at the referendum, etc.), foreigners (for example, the need to obtain a visa to enter a state other than the state of citizenship, in the conduct of business outside the state), stateless persons (need for obtaining a certificate of temporary or permanent residence, obtaining refugee status, etc.);

b) people with disabilities (for example, the need for state guarantees of inclusive education, the development of ram's entrance to buildings, the creation of cars adapted for people with musculoskeletal problems);

c) children (need for state guarantees of maintenance and upbringing by parents before adulthood, enforcement of court decisions on the recovery of alimony for the maintenance of children, etc.);

d) servicemen (need for state guarantees of rehabilitation after participation in military operations, provision of proper monetary and material support, etc.);

e) legal requirements of representatives of other social groups (students, pensioners, judges, etc.);

- according to the subject of satisfaction of legal needs there are: legal requirements that are satisfied by the:

a) public authorities (for example, the need for a person to be registered as an unemployed person in case of impossibility of employment, needs of internally displaced persons in state guarantees of family unity, assistance in returning to their previous place of residence);

b) local self-government authorities (needs for privatization of communal land for conducting economic activity, obtaining permits for reconstruction of a private residential house, etc.);

c) other competent entities (legal entities, public associations, etc.) (for example, the need for qualified legal assistance, education of the appropriate level, and adequate housing and communal services);

d) individuals (need for education for the child, etc.)

- in accordance with the direct involvement of the subject-carrier of these needs in their satisfaction:

1) active (those which provide for the media to be directly involved in their satisfaction, for example, the need to direct appeals to state authorities and local selfgovernment authorities);

2) passive (those which do not require the direct involvement of the media in their satisfaction, such as: the need for normative regulation of public relations through the state, the creation of effective mechanisms for the implementation of rights and freedoms by the state).

The named classifications provide an opportunity to observe a wide range of legal needs and improve the mechanism of satisfying each of their varieties. 


\title{
Список використаних джерел
}

1. Гегель Г. В. Ф. Сочинения [в 14 т]: Т. 8. Философия истории / [пер. с нем.]. Москва, Ленинград: Госиздат, 1935. 468 с.

2. Рабінович П. М. Універсальна теорія права як загальна концептуальна основа теорій національного і міжнародного права (до проблеми формування) // Публічне право. 2017. № 3. C. 18-23.

3. Рабінович П. М. Основи загальної теорії права та держави : навч. посібник. Вид. 10-е, доп. Львів: Край, 2008. 224 с.

\section{References}

1. Hehel', H. V. F. (1935). Sochynenyia [v 14 t]: T. 8. Fylosofyia ystoryy / H. V. F. Hehel' [per. s nem.]. Moskov, Leningrad: Hosyzdat.

2. Rabinovych, P. M. (2017). Universal'na teoriia prava iak zahal'na kontseptual'na osnova teorij natsional'noho i mizhnarodnoho prava (do problemy formuvannia). Publichne pravo, 3, 18-23.

3. Rabinovych, P. M. (2008). Osnovy zahal'noi teorii prava ta derzhavy. L'viv: Kraj.

Стаття: надійшла до редакції 20.09.2017

прийнята до друку 24.10.2017

\section{ЛЮДСЬКІ ПРАВОВІ ПОТРЕБИ: ПОНЯТТЯ, ОСНОВНІ КЛАСИФІКАЦЇ, ЮРИДИЧНИЙ МЕХАНІЗМ ЗАДОВОЛЕННЯ}

\author{
А. Наконечна \\ Львівський національний університет імені Івана Франка, \\ вул. Університетська, 1, Львів, 79000, Україна, \\ e-mail:anna.nakonechna@gmail.com
}

Проаналізовано поняття та юридичний механізм задоволення правових потреб, а також продемонстровано їх основні класифікації.

Такі потреби визначено як потреби людей у якісному позитивно-правовому регулюванні, а також у правовій допомозі.

Висвітлено роль (можливості) кожного з основних елементів (засобів) механізму правового регулювання у задоволенні правових потреб людини, а саме:

- потреба у правосуб'єктності зумовлена тим, що ні фізична, ні юридична особа не можуть існувати й діяти без визнання цієї властивості останніх. Виключно вона надає можливість вчиняти ті чи інші дії;

- потреба у суб'єктивних юридичних правах спричинена тим, що кожна людина потребує правової визначеності своїх дій, оскільки це забезпечує їх правомірність та моральність. Вони слугують свого роду «ключем», наданим державою, для виконання діяльності зі здобуття та споживання, використання певних життєво необхідних благ - об'єктів правовідносин;

- потреба у юридичних джерелах права виникає з огляду на те, що вони юридично закріплюють суб'єктивні права та гарантують їх реалізацію;

- потреба в юридичних фактах пояснюється тим, що саме вони є підставою для виникнення, зміни чи припинення правовідносин, для виникнення суб'єктивних прав громадян у конкретних правовідносинах. Окрім цього, вони є своєрідним засобом переведення правосуб'єктності особи у її суб'єктивне право, а також становлять необхідну ланку у переході від державного нормативного регулювання суспільних відносин до індивідуального правового регулювання; 
- потреба у законності обумовлена тим, що вона $є$ умовою виникнення та функціонування правопорядку, який необхідний для впорядкованості суспільних відносин, а відтак запобігання хаосу та свавілля.

Якість як характеристику правового регулювання відображено такими показниками:

- цінність юридичного регулювання. Вона характеризується його позитивною значущістю для задоволення потреб існування і розвитку людини, соціальних спільнот, об'єднань, усього суспільства;

- економність юридичного регулювання. Характеризується обсягом соціальних витрат, потрібних для досягнення його мети;

- ефективність юридичного регулювання. Характеризується співвідношенням реальних результатів цього регулювання з його метою.

Окрім цього, визначено, що потреба у правовій допомозі зумовлена необхідністю забезпечення правомірної, компетентної реалізації прав і свобод людини, їх захисту та відновлення у разі порушення.

Ключові слова: людська потреба, потреба у правосуб'єктності, потреба у суб'єктивних юридичних правах, потреба у юридичних джерелах права та юридичних фактах, потреба у правозастосувальних та правотлумачних актах. 